\title{
The impact of armed conflict on the prevalence and transmission dynamics of HIV Infection in Libya.
}

\author{
Mohamed Ali Daw ${ }^{1, *}$ \\ https://orcid.org/0000-0003-1312-5956 \\ Email: mohamedadaw@gmail.com
}

Abdallah Hussean El-Bouzedi ${ }^{2}$

Email: abdallaelbouzedi@gmail.com

Mohamed Omar Ahmed ${ }^{3}$

https://orcid.org/0000-0001-7542-886X

Email: a.mo@live.com

${ }^{1}$ Department of Medical Microbiology \& Immunology, Faculty of Medicine, University of Tripoli, CC 82668, Tripoli, Libya

${ }^{2}$ Department of Statistics, Faculty of Science, University of Tripoli, CC 82668, Tripoli, Libya

${ }^{3}$ Department of Microbiology \& Parasitology, Faculty of Veterinary Medicine, University of Tripoli, CC 82668Libya.

* Corresponding author: Mohamed A Daw, MD, FTCDI, Professor of Clinical \& Microbial Epidemiology and Acting Physician of Internal Medicine, Department of Medical Microbiology \& Immunology, Faculty of Medicine, University of Tripoli, Libya 
medRxiv preprint doi: https://doi.org/10.1101/2021.09.20.21263809; this version posted September 23, 2021. The copyright holder for this preprint (which was not certified by peer review) is the author/funder, who has granted medRxiv a license to display the preprint in perpetuity.

It is made available under a CC-BY 4.0 International license .

\begin{abstract}
The interrelationships between HIV/AIDS and armed conflict are a complex phenomenon and studies are rarely devoted to this area of research. Libya is the second-largest country in Africa that has been evoked with war since NATO intervention in 2011. The country has also experienced one of the largest HIV outbreaks associated with the Bulgarian Nurses saga. The effect of the armed conflict on the dynamic spread of HIV is not well known. The objectives of this study were to determine the impact of armed conflict on the epidemiological situation of HIV infection in Libya and analyze the transmission dynamics of HIV strains during the conflict. We investigated the movement of HIV-infected people during the Libyan armed conflict and analyzed the HIV subtypes reported from 2011 to 2020 and followed up the infected cases all over the country. The patterns of HIV spread within the Libyan regions were traced and risk factors were determined during the conflict period. A total of 4539 HIV/AIDS patients were studied from the four regions during the Libyan conflict. Our data analysis indicated that Benghazi the biggest city in the Eastern region was the significant exporter of the virus to the rest of the country. Viral dissemination changes were observed within the country particularly after 2015. A major virus- flow from the Eastern region during the armed conflict associated with internally displaced people. This resulted in a dissemination of new HIV strains and accumulations of HIV cases in Western and Meddle regions. Although, there were no significant changes in the national prevalence of HIV/AIDS. Our data highlights the factors that complicated the spread and dissemination of HIV during the armed conflict which provides a better understanding of the interaction between them. This could be used to plan for effective preventive measures in tackling the spread of HIV in conflict and post-conflict settings.
\end{abstract}

\title{
Keywords: HIV/AIDS. Armed conflict, Libya, Transmutation dynamics, HIV-Migration
}


medRxiv preprint doi: https://doi.org/10.1101/2021.09.20.21263809; this version posted September 23, 2021. The copyright holder for this preprint (which was not certified by peer review) is the author/funder, who has granted medRxiv a license to display the preprint in perpetuity.

It is made available under a CC-BY 4.0 International license .

\section{BACKGROUND}

Human Immune Deficiency Virus (HIV) remains to be a serious problem, particularly within developing countries. Many of the countries affected by HIV are also ravaged by decades of wars and political instability. The interrelationships between armed conflicts and Infectious diseases have been considered inconsistent and studies rarely devoted to these phenomena (1). Armed conflicts and diseases usually link to one another in a positive direction, with violent conflict driving the incidence and prevalence of disease(s) upward. Infectious diseases vary greatly in transmissibility during armed conflicts. Airborne and fecal-oral pathogens such as tuberculosis, cholera, influenza, SARS-CoV 2(COVID-19 pandemic), smallpox, typhus, dengue fever, malaria, plague, and yellow fever can spread easily in conflict situations due to poor sanitation and population movements or refugee flows $(2,3)$. This, however, is not the case of HIV which requires quite specific conditions for transmission. Therefore, studies are needed to highlight the impact of armed conflict on the epidemiological situation of HIV in war-torn countries (4).

Northern African region continues to account for the large majority of the world's HIV/AIDS reported cases in the last decade and it was one of the regions that have been more acutely affected by large-scale violent conflict than other regions in the world (5). Interestingly no studies have been published about the dynamics of the relationship between the two crises. However, epidemiological studies in this area of research are limited and even, indicating an ambiguous and complex relationship between conflict and HIV prevalence levels worldwide. Studies from sub-Saharan Africa showed that at the end of the Angola conflict in 2002, the country's HIV prevalence was relatively lower than the rates in other Southern African countries, 
medRxiv preprint doi: https://doi.org/10.1101/2021.09.20.21263809; this version posted September 23, 2021. The copyright holder for this preprint (which was not certified by peer review) is the author/funder, who has granted medRxiv a license to display the preprint in perpetuity.

It is made available under a CC-BY 4.0 International license .

which suggests that conflict may have slowed HIV spread in this case. Hence then, further studies are needed to highlight the dual-burden of violent conflict and infectious disease $(6,7)$.

Libya, the second-largest country in Africa with the longest coast in the Mediterranean basin has been evoked in a major destructive armed conflict since 2011. During the conflict, health care services were continuously interrupted and the conflict caused massive internal population displacement. Over 1.5 million people have been internally displaced in Libya out of a total population of 6 million (8-10). Furthermore, the country has experienced one of the largest HIV/AIDS outbreaks associated with the Bulgarian Nurses saga in Benghazi in the Eastern region of the country $(11,12)$. Suggesting that parenteral transmission played a role in the spread of HIV in the early epidemic. Since then Libya in cooperation with the European Union has released the Bulgarian nurses and scaled up high efficient scientific research programs to treat the infected victims, introduce a harm-reduction approach and trace the infected individuals $(13,14)$. The program was found to be successful and has been shown to reduce risky practices and HIV transmission among the Libyan population. A community-based study in the country points out that the number of newly registered HIV cases dropped immensely in Libya, HIV prevalence in the general population stands at $>0.05 \%$. Indicating that the epidemiological situation had stabilized (15). This epidemiological stability was disrupted by internal protest in 2011 in the Eastern region complicated by NATO military intervention and a continuous civil war until October $2020(16,17)$.

Human migration and population displacement are likely to have an impact on epidemic dynamics within and among the Libyan regions. HIV Infected people move to new places, they 
might disseminate new viral strains. In addition, new groups of susceptible individuals may be generated, affected by war, with potentially poor access to health care. Hence then an increased export of HIV from the Eastern region ( most heavily HIV-affected region and where the war escalation started) to other Libyan regions are expected $(18,19)$. The dual burdens of HIV/AIDS and armed conflict will be a major obstacle to development in the country. However, little is known about the dynamics of the relationship between the two crises in Libya. Hence then, a clearer understanding of the dynamics of the interface between conflict and HIV is crucial for the development of effective and efficient strategies to reduce population risk. The objectives of this study were to analyze the changes in prevalence and dynamics of HIV-1 subtypes overtime during the Libyan conflict and to determine how the viral infections have been redistributed among the Libyan geographical regions?. 


\section{MATERIALS AND METHODS}

\section{Data Collection}

In Libya, the HIV surveillance system is based on mandatory, anonymous notification of newly diagnosed HIV cases by laboratories all over the country combined with epidemiological information on the mode of transmission and other clinical data, as reported by physicians and trained clinical epidemiologists. We used the data collected from all over Libyan regions of HIVinfected persons during the Libyan conflict from 2011 till, 2020 as shown in Table 1.

\section{Demographic Factors}

Demographic data included were collected for all patients including Gender ( Male/Female), Behavioral data and Transmission risk factors, ( people who inject drugs (PWID), heterosexuals, others, residential area (region, province postcode ), Resident, or displaced, Age category $(<20,20-29,30-39,40-49, \geq 50)$.

\section{Tracing and Migration Pathway}

A comprehensive and detailed follow-up of each patient infected with HIV was carried out during the ten years of the Libyan conflict from 2011 to 2020. This consists of patient location, HIV conditions, and the transmission dynamics. The viral gene flow was indicated as the number of migration events; this is the number of viral strain movements from one location ( i.e region ) to another.

The numbers of HIV-1 subtype migration exportation and importation events were correlated with the epidemiological characteristics of HIV within each region. This includes all the Libyan 
HIV data set infected patients. Epidemiologic data were gained by reconstruction of the migration route

For each region ( West, Central, South \&East), we looked at the following:

- The numbers of exportation viral strain migration events from one region to all of the other regions.

- The numbers of importation viral strain migration events from one region to all of the other regions.

\section{Geographic and Statistical Analysis}

Viral geographic transition flow that might be associated with the military conflict in the East, where the conflict started was traced all over the country and all cases were officially according to the national case report as previously described(5). Chi-square tests of independence for the association of demographic data with HIV subtype were performed in R v3.6.2 (24) using the gplots and corrplots packages $(25,26)$ and linear regression and correlation coincident were calculated in MATLAB® v2020a and regarded a significant with p values < 0.05 (27)

\section{Ethical Approval}

Routinely collected sequence and demographic data on all newly notified HIV-1 infections are linked and irreversibly de-identified to enable public health research in the country as previously described $(15,17)$. The study was approved by the Libyan National Ethical Committee (Approval No. LY NS, HIV473221). It was conducted under the Helsinki Declaration and the supervision of the Libyan Study Group of Hepatitis \& HIV (20, 21). 


\section{RESULTS}

A total of 4539 different strains of HIV were available from the Libyan HIV database. These data were collected for all over the Libyan regions ( West, East. Middle, and South) within ten years period from the start of the armed conflict 2011 till 2020. Of these reported strains $3509(77.3 \%)$ were reported from males and 1030(22.7\%) females( M: F ratio 3:1 ). The number of reported cases varied from one year to another during the study period. They were increased from 371 in 2011 to reach 512 in 2020 and the reported incidence rate (IR,) (number of reported cases/population) $\quad$ rose from $6.0: 100,000$ in 2011 to reach up to $9.0: 100,000 \quad$ in 2020 as shown in Table 1.

The demographic, clinical, and HIV-1 sequences data of the enrolled participants were shown in Table 2. The median age of participants was 37 years [inter-quartile range (IQR) of 26-49 years]. Of 4539 participants involved in the study, 1369 (30.2\%) were from the Eastern region, 1685(37.1\%) Western region, 937(20.6\%) Middle region, and 548(12.1\%) Southern region. A total of 3070 ( $67.4 \%$ ) were reported among resident individuals and 1469 ( $32.4 \%)$ from the displaced population. No variation in the number of reported cases within resident individuals. It was found to be $16 \%$ in 2011 and $17.2 \%$ in 2020 while those reported from displaced individuals increased steadily from $2.9 \%$ in 2011 to $4.7 \%$ (2013-14), $12.6 \%$, and 7.2 $\%$ and then declined to $4.8 \%$ at the end of the conflict period.

The majority of the study participants attributed to IDUs (Injecting Drug users) accounted for $2076(44.7 \%)$. Followed by those with a high-risk sexual behavior 1256( 27.7\%) and 1207( $26.6 \%$ ) with other risk factors. No significant changes were found for transmission risk factors during the investigation period 2011-2020( $P>0.01)$. The proportion of IDUs cases was reported 
medRxiv preprint doi: https://doi.org/10.1101/2021.09.20.21263809; this version posted September 23, 2021. The copyright holder for this preprint (which was not certified by peer review) is the author/funder, who has granted medRxiv a license to display the preprint in perpetuity.

It is made available under a CC-BY 4.0 International license .

to be $(9.3 \%)$ in 2011 and $(10.8 \%)$ in 2020 and ( $5 \%$ to $6.6 \%$ ) for sexual contacts and $6.4 \%$ and 6.4 for other risk factors.

The overall HIV subtype distribution was A (1084(23.9\%), B 2060(45.4\%), CRF02_AG $910(20.1 \%)$, and others $485(10.7 \%)$. The trends of HIV subtypes were changed overtime during the conflict period. There is a substantial difference in the emergence of each subtype during the ten years. We observed an increase in the proportion of subtype B infections from $8.2 \%$ to $10.8 \%$ and subtype A from $4.4 \%$ to $6.7 \%$. For CRF02_AG we found a significant decrease over time as it varied from $4.3 \%$ to $2.2 \%$ during $2011-2020$.

The transmission dynamics of HIV Type 1 in the Libyan Population during the armed conflict was illustrated in Figure 1. The country is classified into twenty-two provinces within the four national regions, the West region ( 7 provinces ), Central region (3 provinces), South region (5 provinces ), and East region ( 7 provinces ). According to the geographic data set analysis, the East region was the main exporter accounting on average for $93.5 \%$ of the migration events in Libya. The geographic strains movements were mostly observed in this region. The most strongly supported viral migration route was found between Benghazi and Tripoli, Benghazi to Misrata. Other routes connecting Benghazi to Sebha and Western Mountains were frequently reported. Other routes of Genetic flow connected Tripoli to the Western mountain, Misrata to Tripoli, and Misrata to Sebha was also reported.

Table 3 illustrates the different HIV-1 strains that migrated from and to different regions during the armed conflict. A total of 972 type-able strains 504(51.9\%) were migrated all over the country. Of these 471 (48.5\%) migrated from the Eastern Region including 321(33.0\%) 
medRxiv preprint doi: https://doi.org/10.1101/2021.09.20.21263809; this version posted September 23, 2021. The copyright holder for this preprint (which was not certified by peer review) is the author/funder, who has granted medRxiv a license to display the preprint in perpetuity.

It is made available under a CC-BY 4.0 International license .

recombinant $\mathrm{CROF}$, followed by $\mathrm{B}$ 143( $14.7 \%)$ and only $7(0.7 \%)$ and HIV-1 A. The meddle region received $17(1.7 \%$ ) migrated stains ( $9 \mathrm{CROF}$, 6A 2B), followed by Western Region 9 $(0.9 \%)$ strains and only 7 ( $0.7 \%)$ Southern Region.

Furthermore, $468(48.1 \%)$ strains were migrated to different regions including, $319(32.8 \%)$ migrated to The western region particularly Tripoli, including $\quad$ B $224(23 \%) \quad$ C 82( 8.4\%) A13 (1.311\%), followed by Meddle region $107(\%)$ A 09(9.0\%) B 75(7.7\%) C 23(2.4\%).Although only $39(4.0 \%)$ and only 3 Strains migrated to Eastern and southern regions respectively.

The prevalence of HIV and the distribution of multiple HIV subtypes in different geographic locations during the Libyan conflict were presented in Figure 2. In the first five years period ( 2011-2015 -Figure 2A), the Eastern region showed the highest prevalence of HIV particularly in Benghazi estimated to be $>0.8 \%$ followed by Marj, Darna, and Butnan and to less extent Al Wahat and Kufra. In these provinces, CROF was the predominant circulating strain accounted for $60 \%$ followed by Strain B with $20 \%$. In the West region, Tripoli reported a HIV prevalence of $6 \%$ followed by Nalut $4 \%$ others are less than $0.2 \%$. In the Western provinces, HIV-B was the predominant strain which has reached $50 \%$ followed by HIV-A and CROF which accounted for $20 \%$ each. In Central province, HIV prevalence was reported to be $0.6 \%$ in Misrata followed by Sirte and Jufra. HIV -B and CROF were the predominant circulating strains, where they occupied $45 \%$ and $25 \%$ respectivelly. In the South region the HIV prevalence was reported to be very low $(<0.4 \%)$. The predominant circulating strains in these provinces were $\mathrm{B}(40 \%),, \mathrm{A}(30 \%)$, and to less extent $\mathrm{CROF}(20 \%)$. 
In the second period of the conflict ( 2016-2020) Figure 2B. The Western region showed a higher HIV prevalence. The highest prevalence was reported in Tripoli, Zawia, Nuqat AlKhams, Jafra,Murqub, Nalut, and to less extent Jabl-Al Garbi. In these provinces, the highestcirculating HIV strains were B (40\%) CROF (35\%), and A (20\%). In the Central region the highest prevalence was reported in Misrata $(>0.8 \%)$ and only $<0.2 \%$ in Sirte and Jufra. HIVstrain B accounted for $40 \%$ of the circulating strains followed by CROF( 35\%) and B (20\%). In the Southern provinces, the HIV prevalence reached $0.6 \%$ in Sabha and Ghat and $4 \%$ in the other three provinces. The most circulating strains occupy the Southern provinces were Strains A\&B accounted for $30 \%$ each followed by CROF (25\%). In the Eastern region HIV prevalence was $0.6 \%$ in Benghazi and $<0.2$ in the other provinces. Furthermore, the most predominant circulating strains were B (25\%), CROF (25\%), and A (20\%). 
medRxiv preprint doi: https://doi.org/10.1101/2021.09.20.21263809; this version posted September 23, 2021. The copyright holder for this preprint (which was not certified by peer review) is the author/funder, who has granted medRxiv a license to display the preprint in perpetuity.

It is made available under a CC-BY 4.0 International license .

\section{DISCUSSION}

Armed-Conflicts may have profound effects on the spread and dissemination of the HIV pandemic which should be considered. A long period of conflicts has resulted in greater naïveté regarding the epidemiology and prevention of the disease in Sub-Saharan and North African countries (22). In this study, we investigated the dissemination and spread of HIV during the armed conflict in Libya by analyzing the spatial and temporal patterns of the viral flow during the ten years of the conflict. Our data indicated that HIV- reported strains have moved from the regions involved in the armed -conflict to the rest of the country. The Eastern region was the most exporter of HIV strains, as it appears that the strains were originated directly or indirectly from Benghazi; the largest city in the East region. The east location is heavily affected by HIV before and at an early stage of the armed conflict. Within the period of 2011-2014, a total of 1755 cases were reported in the eastern region accounting for $38.7 \%$ of all nationally registered cases of HIV infection.

Demographic analysis in this study indicated that the highest HIV prevalence was reported among IDUs accounting for 2076 (45.2\%) cases followed by sexual activities 1256 (27.7\%) cases. This was mainly common among the middle age group of (30-39) years followed by 40-49 ). Though it was less among other age groups. The genetic analysis has shown HIV-1 subtype A accounted for 2060(45.4\%) cases followed by HIV-1 subtype A 1084(23.9\%) and to less extent CRF02_AG, for 910 (20.1\%). As IDUs are a main contributing factor among war internal displacement in the study. This may create a favorable environment for new HIV transmission and facilitate the generalization of the HIV epidemic in Libya. Similar studies on HIV in conflict-affected settings in Africa suggest that regions that have received new imported HIV strains also have appropriate conditions for those strains to flourish $(23,24)$. 
medRxiv preprint doi: https://doi.org/10.1101/2021.09.20.21263809; this version posted September 23, 2021. The copyright holder for this preprint (which was not certified by peer review) is the author/funder, who has granted medRxiv a license to display the preprint in perpetuity. It is made available under a CC-BY 4.0 International license .

The prevalence of HIV and the spread of HIV-1 subtypes have experienced tremendous changes during the Libyan armed conflict. Our study has shown the inter-location of HIV strains within the Libyan regions is an emerging phenomenon. The number of viral exportation correlates well with the number HIV infected patients in each region. We have observed more infected people moved from the locations from which the virus is originating. This is evident in our study as more HIV-infected individuals moved from the main exporting locations ( this is Benghazi at Eastern region) to the main importing locations particularly at the Western region ( i.e Tripoli) and Meddle region ( Musrta). This inter-location has resulted in a major change in the prevalence of HIV infection and the dissemination of HIV strains within the Libyan region. Before and during the early stage of the conflict the HIV prevalence was similar among most of the Libyan regions. While it has been geographically inter-located since then. In the Eastern region where the conflict has exsanguinated, it was changed drastically from $0.6-0.8 \%$ in (2011$2015)$ to $0.2-0.4 \%$ (2016-2020). Although the western and Meddle region was escalated from $0.2-0.6 \%$ ( 2011-2015) to $0.4-0>0.8$ during 2016-2020. With no significant change in the national prevalence of HIV and HIV strains during the conflict period ( 2011-2020).

Population displacement is a major consequence of armed conflict which reflects greatly on the health of displaced people. In Libya, over 250,000 people were displaced in 2011 this was further increased as the armed conflict escalated from 2014 to 2020 . This could be reflected in the epidemiological patterns of microbial disease and health conditions of the displaced people including HIV Infected individuals $(25,26)$.). In this study, major transition patterns of the viral strains movements during the armed conflict have been reported. HIV-subtype CRF02_AG; the main strain resident in the East region and rarely reported in the other Libya regions before 2011 
medRxiv preprint doi: https://doi.org/10.1101/2021.09.20.21263809; this version posted September 23, 2021. The copyright holder for this preprint (which was not certified by peer review) is the author/funder, who has granted medRxiv a license to display the preprint in perpetuity.

It is made available under a CC-BY 4.0 International license .

accounted for $68 \%$ of the migrated strains to the other regions particularly the west and central regions. The number of the exported strains correlated well with the number of registered HIV cases in each region. More infected people have moved away from the conflict zone to a more secured area. This reflects the redistribution of preexisting infections within the country. Many resident people who were initially infected in the eastern region have moved to central and meddle regions due to war, resulting in a redistribution of HIV viral strains within the country. This is in concordance with other data reported from other countries inflated by war such as Uganda and Ukraine(27,28). Furthermore, population displacement may be reflected in the treatment of HIV-infected individuals as patients who had to relocate because of the conflict may be more likely to reduce treatment adherence. Hence then the spread of HIV-1 strains is becoming a serious public health challenge that requires further studies to understand deeply their origin and distribution (29).

Different comments should be raised concerning the limitations of this study. First, the study is carried during the conflict time where not all the needed data are easily available or accurately reported. Second, our data is based on the officially reported cases of HIV-infected patients and the number of typed stains. Hence then caution is advised regarding the exact number of HVI infected cases in the present study which may not be representative of the real HIV population in the country. Hence then further studies are needed at the post-conflict period to improve the accuracy of the number of HIV migrant strains that fit the population distribution with the Libyan regions $(30,31)$. However, this study indicated clearly that human migration dynamics may play a key role in the dissemination of new viral strains and influenced the risk of HIV. This may exacerbate vulnerability and accelerates the spread of HIV in post-conflict 
medRxiv preprint doi: https://doi.org/10.1101/2021.09.20.21263809; this version posted September 23, 2021. The copyright holder for this preprint (which was not certified by peer review) is the author/funder, who has granted medRxiv a license to display the preprint in perpetuity.

It is made available under a CC-BY 4.0 International license .

settings. Such juxtaposition which is evident in this study has already been reported to some extent in certain African countries including Mozambique(32). Unfortunately, the international community that intervened in 2011 and initiated this armed conflict, has compartmentalized its responses to HIV and conflict in Libya. Therefore, efforts should be combined and studies are needed to formulate long-run policies to precludes an integrated and aggressive attack on the HIIV in Libya $(33,34)$.

\section{CONCLUSION}

This is the first study to investigate the impacts of the armed conflict on the epidemiological patterns of HIV infection in Libya using spatial and temporal analysis. Our findings support the initial spread of HIV infections and HIV strains providing quantitative measurements of the spread and dissemination of the infection at regional and national levels. These findings contribute greatly to the fundamental understanding of the patterns and transmission dynamics of HIV during the armed conflict. The migration of HIV strains represents an enormous surveillance challenge. Hence then national intervention policies during and at post-conflict periods should be implemented considering such understanding $(35,36)$. 


\section{DATA AVAILABILITY STATEMENT}

The data presented in this paper are freely available upon request

\section{AUTHOR CONTRIBUTIONS}

MD conceived and designed the study, wrote the paper, designed the analysis, analyzed the data, and performed cartography. MD and AE-B contributed to the analysis tools. AE-B and MA made substantial contributions to conception and design, acquisition of data, or analysis and interpretation of data. MD, MA, and AE-B provided advice and critically reviewed the manuscript. All authors read and approved the final manuscript

\section{ACKNOWLEDGMENTS}

We are deeply grateful to the Libyan Study Group of Hepatitis \& HIV and the Department of Medical Microbiology, Faculty of Medicine, University of Tripoli, for their help and support. 


\section{REFERENCES}

1-Paxton NA. Plague and war: political breakdown and the spread of HIV. Med Confl Surviv. 2016 Oct-Dec;32(4):255-281. doi: 10.1080/13623699.2016.1265872. Epub 2017 Jan 16. PMID: 2809298

2- Paxton NA. Plague and war: political breakdown and the spread of HIV. Med Confl Surviv. 2016 Oct-Dec;32(4):255-281. doi: 10.1080/13623699.2016.1265872. Epub 2017 Jan 16. PMID: 28092985.

3- Letendre K, Fincher CL, Thornhill R. Does infectious disease cause global variation in the frequency of intrastate armed conflict and civil war? Biol Rev Camb Philos Soc. 2010 Aug;85(3):669-83. doi: 10.1111/j.1469-185X.2010.00133.x. Epub 2010 Apr 1. PMID: 20377573.

4-Bennett BW, Marshall BD, Gjelsvik A, McGarvey ST, Lurie MN. HIV Incidence Prior to, during, and after Violent Conflict in 36 Sub-Saharan African Nations, 1990-2012: An Ecological Study. PLoS One. 2015 Nov 12;10(11):e0142343. doi: 10.1371/journal.pone.0142343. PMID: 26562434; PMCID: PMC4642881. 
5- Daw MA, Ahmed MO. Epidemiological characterization and geographic distribution of human immunodeficiency virus/acquired immunodeficiency syndrome infection in North African countries. World J Virol. 2021 Mar 25;10(2):69-85. doi: 10.5501/wjv.v10.i2.69. PMID: 33816152; PMCID: PMC7995411.

6-Mock NB, Duale S, Brown LF, Mathys E, O'maonaigh HC, Abul-Husn NK, Elliott S. Conflict and HIV: A framework for risk assessment to prevent HIV in conflict-affected settings in Africa. Emerg Themes Epidemiol. 2004 Oct 29;1(1):6. doi: 10.1186/1742-7622-1-6. PMID: 15679919; PMCID: PMC544944.

7-Mills EJ, Singh S, Nelson BD, Nachega JB. The impact of conflict on HIV/AIDS in subSaharan Africa. Int J STD AIDS. 2006 Nov;17(11):713-7. doi: 10.1258/095646206778691077. PMID: 17062170.

8-Daw MA, El-Bouzedi A, Dau AA. Libyan armed conflict 2011: mortality, injury and population displacement. African Journal of Emergency Medicine. 2015 Sep 1;5(3):101-7.

9-Daw MA, El-Bouzedi AH, Dau AA. Trends and patterns of deaths, injuries and intentional disabilities within the Libyan armed conflict: 2012-2017. PLoS One. 2019 May 10;14(5):e0216061. doi: 10.1371/journal.pone.0216061. PMID: 31075119; PMCID: PMC6510427. 
10-Daw MA, El-Bouzedi A, Dau AA. The assessment of efficiency and coordination within the Libyan health care system during the armed conflict-2011. Clinical Epidemiology and Global Health. 2016 Sep 1;4(3):120-7.

11-Zalon ML. Bulgarian nurses appeal Libyan death sentence. Pa Nurse. 2005 Mar;60(2):22. PMID: 15909622.

12- Bagasra O, Alsayari M, Bullard-Dillard R, Daw MA. The Libyan HIV Outbreak How do we find the truth? Libyan J Med. 2007 Jun 1;2(2):57-62. doi: 10.4176/070221. PMID: 21503253; PMCID: PMC3078273.

13-Parish LC. Freedom for the Bulgarian nurses and a Palestinian doctor. Clin Dermatol. 2008 Sep-Oct;26(5):574. doi: 10.1016/j.clindermatol.2007.11.009. PMID: 18755378

14-van Zyl T. Libya negotiates deal for release of doctor, 5 nurses. CMAJ. 2007 Aug 28;177(5):448. doi: 10.1503/cmaj.071075. PMID: 17724320; PMCID: PMC1950179 
15- Daw MA, El-Bouzedi A, Ahmed MO, Dau AA; In association with the Libyan Study Group of Hepatitis \& HIV. Molecular and epidemiological characterization of HIV-1 subtypes among Libyan patients. BMC Res Notes. 2017 Apr 28;10(1):170. doi: 10.1186/s13104-017-2491-2. PMID: 28454556; PMCID: PMC5410017.

16-Daw MA. Libyan healthcare system during the armed conflict: Challenges and restoration. Afr J Emerg Med. 2017 Jun;7(2):47-50. doi: 10.1016/j.afjem.2017.04.010. Epub 2017 May 9. PMID: 30456107; PMCID: PMC6234156.

17-Daw MA, Daw AM, Sifennasr NEM, Draha AM, Daw AA, Daw AA, Ahmed MO, Mokhtar ES, El-Bouzedi AH, Daw IM, Adam SI, Warrag S; In association with Libyan Study Group of Hepatitis \& HIV. Spatiotemporal analysis and epidemiological characterization of the human immunodeficiency virus (HIV) in Libya within a twenty-five-year period: 1993-2017. AIDS Res Ther. 2019 Jun 25;16(1):14. doi: 10.1186/s12981-019-0228-0. PMID: 31238947; PMCID: PMC6591977.

18-Lebedev A, Pasechnik O, Ozhmegova E, Antonova A, Blokh A, Grezina L, Sandyreva T, Dementeva N, Kazennova E, Bobkova M. Prevalence and spatiotemporal dynamics of HIV-1 Circulating Recombinant Form 03_AB (CRF03_AB) in the Former Soviet Union countries. PLoS One. 2020 Oct 23;15(10):e0241269. doi: 10.1371/journal.pone.0241269. Erratum in: PLoS One. 2021 Feb 19;16(2):e0247611. PMID: 33095842; PMCID: PMC7584246. 
19-Vasylyeva TI, Liulchuk M, Friedman SR, Sazonova I, Faria NR, Katzourakis A, Babii N,

Scherbinska A, Thézé J, Pybus OG, Smyrnov P, Mbisa JL, Paraskevis D, Hatzakis A,

Magiorkinis G. Molecular epidemiology reveals the role of war in the spread of HIV in Ukraine.

Proc Natl Acad Sci U S A. 2018 Jan 30;115(5):1051-1056. doi:

20- Deklaracja Helsińska Swiatowego Stowarzyszenia Lekarzy (WMA). Etyczne zasady prowadzenia badań medycznych z udziałem ludzi [The Helsinki Declaration of the World Medical Association (WMA). Ethical principles of medical research involving human subjects]. Pol Merkur Lekarski. 2014 May;36(215):298-301. Polish. PMID: 24964504.

21-Daw MA, Shabash A, El-Bouzedi A, Dau AA; Association with the Libyan Study Group of Hepatitis \& HIV. Seroprevalence of HBV, HCV \& HIV co-infection and risk factors analysis in Tripoli-Libya. PLoS One. 2014 Jun 17;9(6):e98793. doi: 10.1371/journal.pone.0098793. PMID: 24936655; PMCID: PMC4060988.

22- Sam-Agudu NA, Folayan MO, Haire BG. Program implementation gaps and ethical issues in the prevention of HIV infection among infants, children, and adolescents in sub-Saharan Africa. Pediatric research. 2020 Jan;87(2):406-13. 
23- Mock NB, Duale S, Brown LF, Mathys E, O'maonaigh HC, Abul-Husn NK, Elliott S.

Conflict and HIV: A framework for risk assessment to prevent HIV in conflict-affected settings in Africa. Emerging themes in epidemiology. 2004 Dec;1(1):1-6.

24- Kim Y. Armed conflict, health spending, and HIV. The International journal of health planning and management. $2018 \mathrm{Jul} ; 33(3): 581-95$.

25-Lichtenheld AG. Explaining population displacement strategies in civil wars: a cross-national analysis. International Organization. 2020;74(2):253-94.

26- Gatrell P. Introduction: world wars and population displacement in Europe in the twentieth century. Contemporary European History. 2007 Nov;16(4):415-26.

27- Williams LD, Korobchuk A, Smyrnov P, Sazonova Y, Nikolopoulos GK, Skaathun B, Morgan E, Schneider J, Vasylyeva TI, Duong YT, Chernyavska S. Social network approaches to locating people recently infected with HIV in Odessa, Ukraine. Journal of the International AIDS Society. 2019 Jun;22(6):e25330.

28- Grabowski MK, Serwadda DM, Gray RH, Nakigozi G, Kigozi G, Kagaayi J, Ssekubugu R, Nalugoda F, Lessler J, Lutalo T, Galiwango RM. HIV prevention efforts and incidence of HIV in Uganda. New England Journal of Medicine. 2017 Nov 30;377(22):2154-66. 
29- Rich SN, Richards VL, Mavian CN, Switzer WM, Rife Magalis B, Poschman K, Geary S, Broadway SE, Bennett SB, Blanton J, Leitner T. Employing molecular phylodynamic methods to identify and forecast HIV transmission clusters in public health settings: A qualitative study. Viruses. 2020 Sep;12(9):921.

30-Mugisha J, Muyinda H, Kagee A, Wandiembe P, Kiwuwa SM, Vancampfort D, Kinyanda E. Prevalence of suicidal ideation and attempt: associations with psychiatric disorders and HIV/AIDS in post-conflict Northern Uganda. African health sciences. 2016;16(4):1027-35.

31- Becker JU, Theodosis C, Kulkarni R. HIV/AIDS, conflict and security in Africa: rethinking relationships. Journal of the International AIDS Society. 2008 Dec;11(1):1-7.

32-Korenromp EL, Gobet B, Fazito E, Lara J, Bollinger L, Stover J. Impact and cost of the HIV/AIDS national strategic plan for Mozambique, 2015-2019_Projections with the Spectrum/Goals Model. PloS one. 2015 Nov 13;10(11):e0142908.

33-Yogo UT, Mallaye D. Health aid and health improvement in Sub $\square$ Saharan Africa: Accounting for the heterogeneity between stable states and post $\square$ conflict states. Journal of International Development. 2015 Oct;27(7):1178-96.

34-Smith MK, Xu RH, Hunt SL, Wei C, Tucker JD, Tang W, Luo D, Xue H, Wang C, Yang L, Yang B, Li L, Joyner BL Jr, Sylvia SY. Combating HIV stigma in low- and middle-income 
medRxiv preprint doi: https://doi.org/10.1101/2021.09.20.21263809; this version posted September 23, 2021. The copyright holder for this preprint (which was not certified by peer review) is the author/funder, who has granted medRxiv a license to display the preprint in perpetuity. It is made available under a CC-BY 4.0 International license .

healthcare settings: a scoping review. J Int AIDS Soc. 2020 Aug;23(8):e25553. doi:

10.1002/jia2.25553. PMID: 32844580; PMCID: PMC7448195.

35-Giovanetti M, Ciccozzi M, Parolin C, Borsetti A. Molecular epidemiology of HIV-1 in African countries: a comprehensive overview. Pathogens. 2020 Dec;9(12):1072.

36-Tiemessen CT. The many faces of HIV elite control. EBioMedicine. 2021 Apr;66. 


\section{Tables and Figures}

\section{Tables}

Table 1; Number of reportedly HIV-infected people during the Libyan armed conflict in ten years (2011-2020).

Table 2; Demographic characteristics of HIV-infected population during the Libyan armed conflict.

Table 3; Inter-location series of HIV-1 strains in Libya during the armed conflict

\section{Figures}

Figure 1; The migration and expansion patterns of HIV cases during the conflict time 2011-

2020. The arrows indicate the directionality of virus flow movement from the residential location.

Figure 2; The regional prevalence of HIV and geographic distribution of HIV-1 subtypes during the Libyan conflict A- the period from 2011 to 2015 B-period 2016 to 2020

Figure 3. Trends of the prevalence of different HIV-1 subtypes in Libya during the armed conflict- 2011-2020 
medRxiv preprint doi: https://doi.org/10.1101/2021.09.20.21263809; this version posted September 23, 2021. The copyright holder for this preprint (which was not certified by peer review) is the author/funder, who has granted medRxiv a license to display the preprint in perpetuity. It is made available under a CC-BY 4.0 International license .

Table 1; Number of reportedly HIV-infected people during the Libyan armed conflict in ten years (2011-2020).

\begin{tabular}{|c|c|c|c|c|}
\hline Year & No. Cases* & Male & Female & Ratio \\
\hline 2011 & 371 & 293 & 78 & $4: 1$ \\
\hline 2012 & 486 & 385 & 101 & $4: 1$ \\
\hline 2013 & 459 & 338 & 121 & $3: 1$ \\
\hline 2014 & 439 & 359 & 80 & $4: 1$ \\
\hline 2015 & 511 & 372 & 139 & $3: 1$ \\
\hline 2016 & 309 & 212 & 97 & $2: 1$ \\
\hline 2017 & 471 & 382 & 89 & $4: 1$ \\
\hline 2018 & 492 & 387 & 105 & $3: 1$ \\
\hline 2019 & 489 & 382 & 107 & $4: 1$ \\
\hline 2020 & 512 & 399 & 113 & $4: 1$ \\
\hline Total & 4539 & 3509 & 1030 & $3: 1$ \\
\hline
\end{tabular}

Number of seroincident individuals*. 
Table 2; Demographic characteristics of HIV infected population during the Libyan armed conflict-2011-2020

Study period

$\begin{array}{llllll}2011- & 2013- & 2015- & 2017- & 2019- & \text { Total }(\%) \\ 2012 & 2014 & 2016 & 2018 & 2020 & \end{array}$

No of cases

$\begin{array}{llllll}857 & 898 & 820 & 963 & 1001 & 4539\end{array}$

Study Location (Region)

$\begin{array}{lcccccc}\text { East } & 379 & 394 & 198 & 178 & 219 & 1369(30.2) \\ \text { West } & 237 & 279 & 397 & 421 & 351 & 1685(37.1) \\ \text { Meddle } & 129 & 126 & 131 & 262 & 289 & 937(20.6) \\ \text { South } & 112 & 99 & 94 & 101 & 142 & 548(12.1)\end{array}$

Movement status

$\begin{array}{lllllll}\text { Resident } & 726 & 681 & 247 & 634 & 782 & 3070(66) \\ \text { Displaced } & 131 & 217 & 573 & 329 & 219 & 1469(34)\end{array}$

Age Category

$\begin{array}{ccccccc}<20 & 93 & 71 & 47 & 43 & 67 & 321(7.0) \\ 20-29 & 246 & 194 & 125 & 127 & 287 & 979(21.3) \\ 30-39 & 523 & 471 & 311 & 205 & 582 & 2092(45.5) \\ 40-49 & 230 & 181 & 117 & 198 & 291 & 1017(22.1) \\ \geq 50 & 73 & 32 & 21 & 27 & 31 & 184(4.0)\end{array}$


medRxiv preprint doi: https://doi.org/10.1101/2021.09.20.21263809; this version posted September 23, 2021. The copyright holder for this preprint (which was not certified by peer review) is the author/funder, who has granted medRxiv a license to display the preprint in perpetuity.

It is made available under a CC-BY 4.0 International license .

Transmission Risk Factor

$\begin{array}{lcccccc}\text { IDUs } & 421 & 379 & 357 & 428 & 491 & 2076(45.2) \\ \text { Sexual activity } & 209 & 228 & 231 & 287 & 301 & 1256(27.3) \\ \text { Others/Unknown } & 227 & 291 & 232 & 248 & 209 & 1207(26.3) \\ \text { Total } & 857 & 898 & 820 & 963 & 1001 & 4539\end{array}$

HIV-1 subtype

1469

$\begin{array}{lcccccc}\text { A } & 201 & 195 & 159 & 218 & 311 & 1084(23.9) \\ \text { B } & 370 & 414 & 365 & 421 & 490 & 2060(45.4) \\ \text { CRFo2_AG } & 197 & 202 & 193 & 216 & 102 & 910(20.1) \\ \text { NI* } & 89 & 87 & 103 & 108 & 98 & 485(10.7)\end{array}$

NI*: Non-Identifiable 
medRxiv preprint doi: https://doi.org/10.1101/2021.09.20.21263809; this version posted September 23, 2021. The copyright holder for this preprint (which was not certified by peer review) is the author/funder, who has granted medRxiv a license to display the preprint in perpetuity.

It is made available under a CC-BY 4.0 International license .

Table 3; Inter-location series of HIV-1 strains in Libya during the armed conflict 2011-2010

No cases(\%)

Location

West Region

\section{Tripoli}

Meddle Region

\section{Misrata}

East Region

$$
\text { Benghazi }
$$

South Region
Sebha
Migrated to (\%)

Total

319

107

09

75

23

17

2

06

09

Migrated from (\%)
A

B CROF Total

82

9

1

5

3

A $\quad$ B $\quad$ CROF

$39 \quad 07$

19

13

471

$7 \quad 143$

321

0

\begin{abstract}
02
\end{abstract}
01

07

4

3

0 


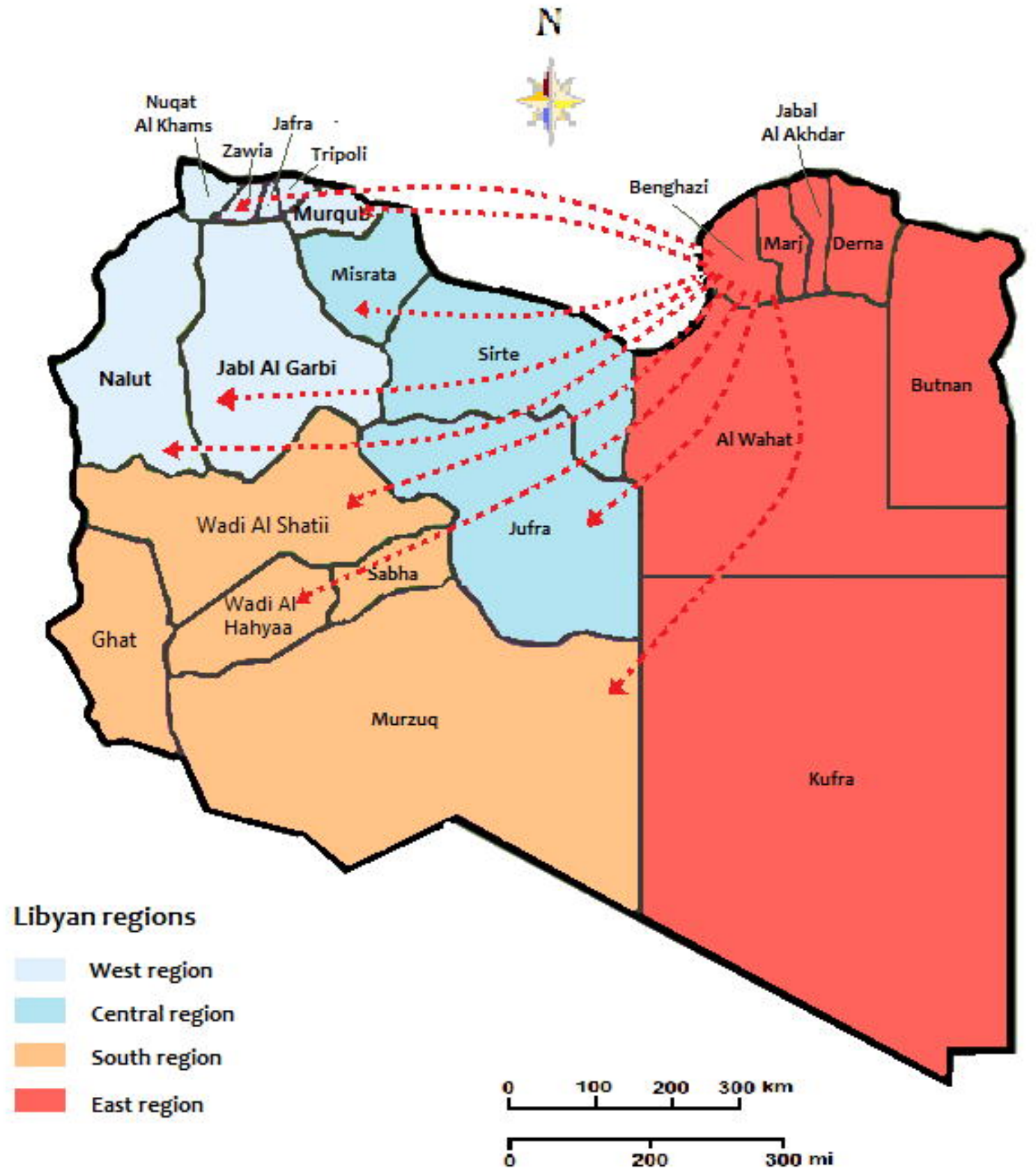




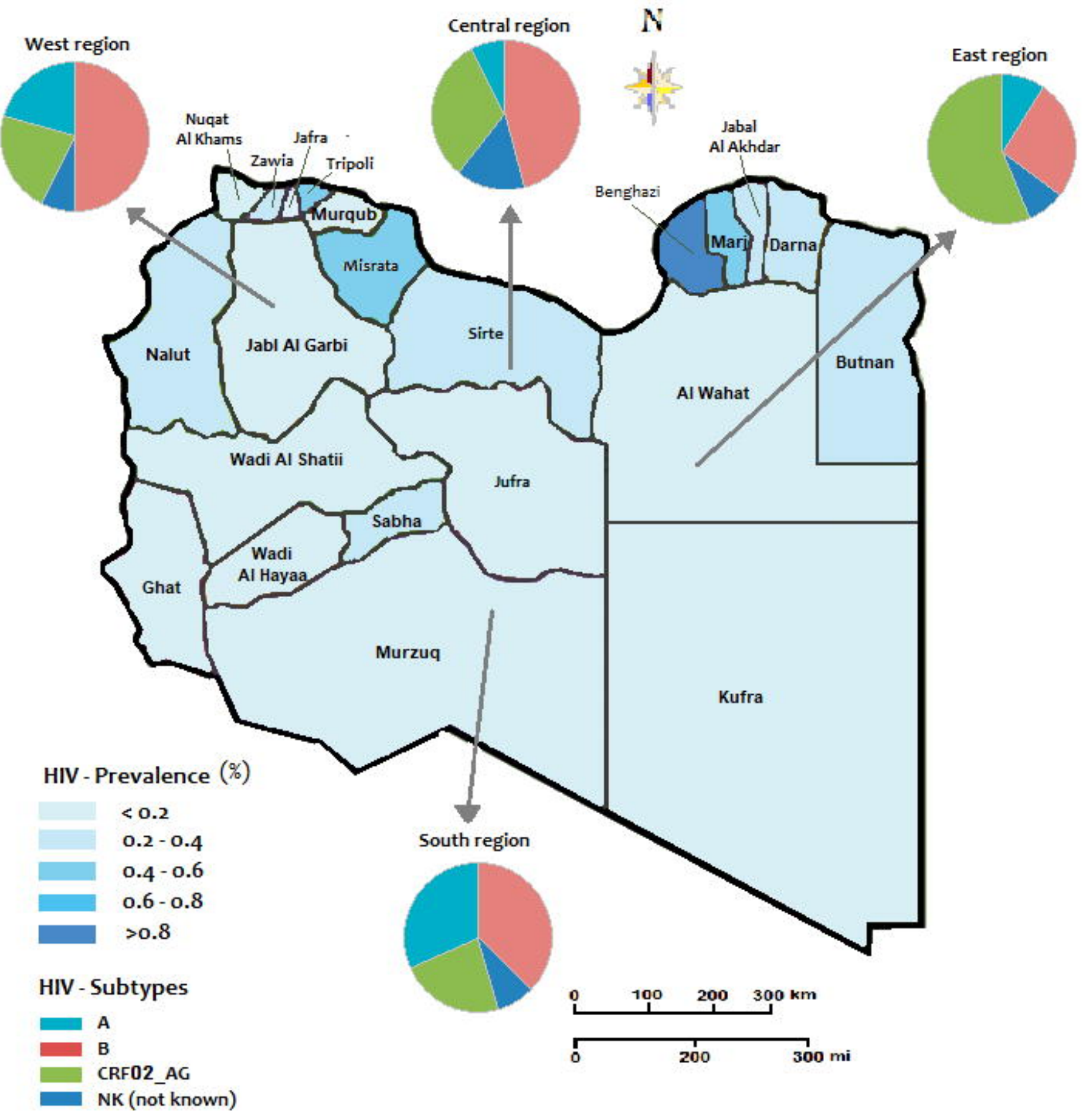




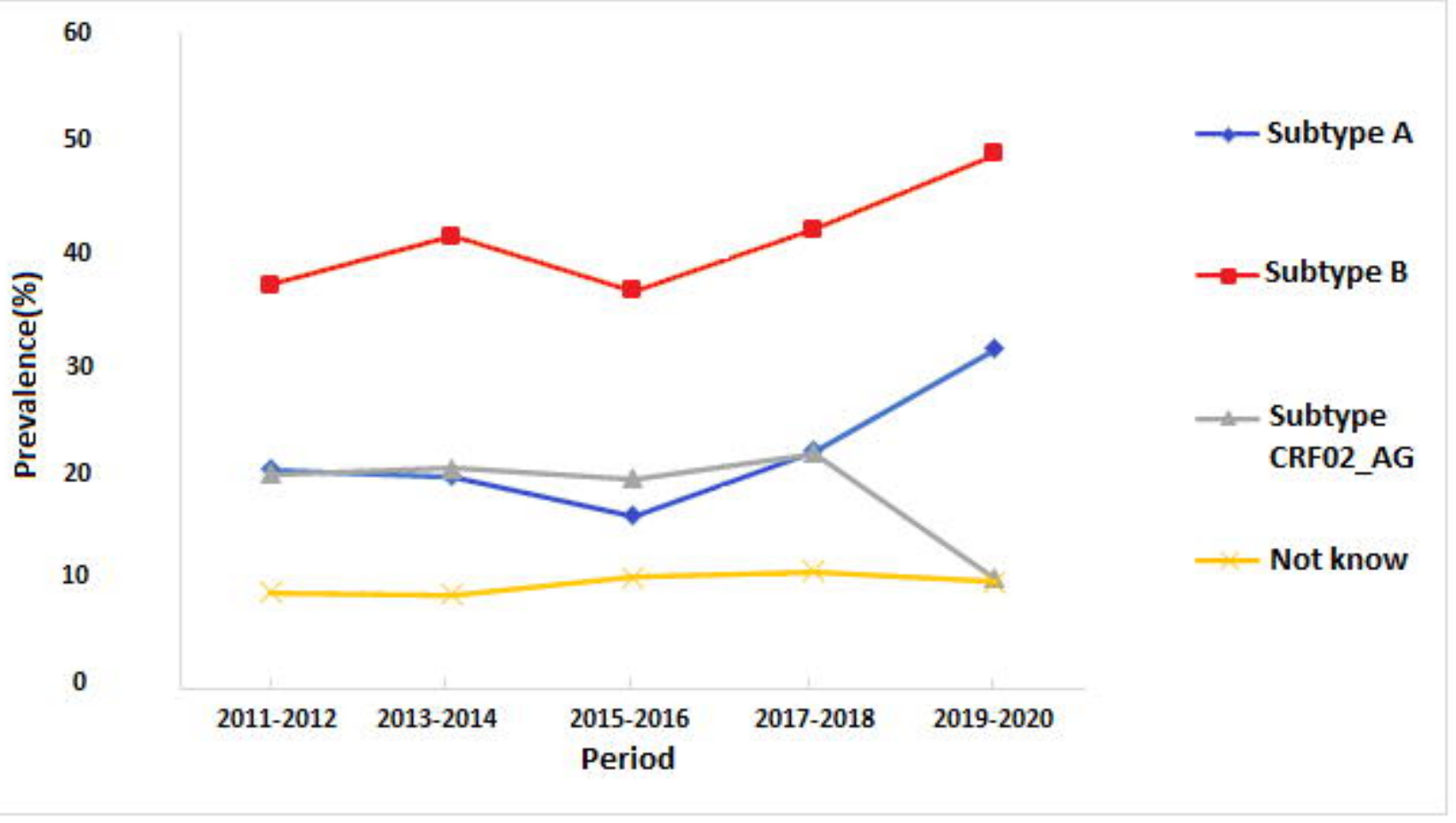

